\section{Physiological Changes in Roma-type Tomato Induced by Mechanical Stress at Several Ripeness Stages}

\author{
Eunkyung Lee, Steven A. Sargent, ${ }^{1}$ and Donald J. Huber \\ Horticultural Sciences Department, University of Florida/IFAS, P.O. \\ Box 110690, Gainesville, FL 32611-0690
}

Additional index words. Solanum lycopersicum, ripeness stage, harvest maturity, impact, electrolyte leakage, PG activity

\begin{abstract}
Roma tomatoes ('BHN 467') were hand-harvested at mature-green color stage and treated with ethylene $\left(100 \mu \mathrm{L} \cdot \mathrm{L}^{-1}\right.$ at $20{ }^{\circ} \mathrm{C}$ and $90 \%$ relative humidity) until reaching breaker $(<10 \%$ red), pink $(30 \%-60 \%$ red $)$, or light-red ripeness stage $(60 \%-90 \%$ red). Individual fruit at each ripeness stage were subjected to double impacts over the locule using a pendulum-impact device with a force equivalent to two $40-\mathrm{cm}$ drops, followed by ripening at $20^{\circ} \mathrm{C}$. Fruit exhibited most noticeable increases in respiration and ethylene production within 1 hour and 1 day after impact, respectively. After 24 hours, respiration rates increased $40 \%-60 \%$ regardless of ripeness stage, while ethylene production in impacted breaker-stage fruit increased 3-fold (to $6.7 \mu \mathrm{L} \cdot \mathrm{kg}^{-1} \cdot \mathrm{h}^{-1}$ ). Fruit impacted at breaker stage softened 2 days earlier compared with non-impacted breaker fruit. Fruit impacted at all ripeness stages had higher electrolyte leakage and polygalacturonase (PG) activity during ripening than non-impacted fruit. After 6 days, electrolyte leakage in fruit impacted at light-red ripeness stage was $23 \%$ higher than non-impacted fruit; PG activity in breaker fruit increased $40 \%$ at 10 days over non-impacted fruit. No changes were observed for soluble solids content, total titratable acidity, $\mathrm{pH}$, or sugar/acid ratio from impacts, independent of ripeness stage.
\end{abstract}

\section{Introduction}

Roma-type tomato, also called the Italian tomato or plum tomato, is one of most popular specialty tomatoes. This small, pear-shaped fruit is very prolific, has lower water content than standard round-type tomato, and has rich flavor, so it has been traditionally used for canning, puree, or paste. Compared with cherry tomato, plum tomato fruits were reported to have lower acid content, higher lycopene content, and more reddish skin color (Muratore et al., 2005). Clark et al. (1999) also noted that cracking was not a problem because the Roma-type fruit was much firmer than slicing tomatoes.

Increased use of mechanical equipment for the harvesting, packing, and transporting fruits and vegetables has led to mechanical injury becoming a more significant problem (Brusewitz and Bartsch, 1989; Marshall and Brook, 1999). Sargent et al. (1992) reported that tomato fruits were subjected to several impacts during handling and packing, undergoing at least 15 handling steps. The proportion of visibly damaged tomatoes increased from $15 \%$ before to $35 \%$ after dumping (O'Brien et al., 1972), while internal bruising increased from $5.2 \%$ to $23.8 \%$

Received for publication 16 Jan. 2007. Accepted for publication $13 \mathrm{Apr} .2007$.

${ }^{1}$ To whom reprint requests should be addressed; e-mailsasa@ufl.edu for tomatoes sampled from the float tank and the grading table, respectively (Sargent et al., 1989).

Mechanical injury has been correlated with metabolic disorders and quality changes in fruits and vegetables. Decreased soluble solids content in grape (Morris et al., 1979), decreased firmness in cucumber (Miller et al., 1987), and changes in aroma volatiles in round-type tomato (Moretti et al., 2002) were induced by mechanical impact. MacLeod et al. (1976) reported that $\mathrm{C}_{2} \mathrm{H}_{4}$ production increased within $1 \mathrm{~h}$ after drop impacts in round-type tomato. Moretti et al. (1998) reported that bruised locular tissue of tomato contained $\approx 15 \%$ less vitamin $\mathrm{C}$ content than nonbruised tomatoes.

The stage of fruit ripeness at harvest is one of major factors influencing the susceptibility of commodity to mechanical injury; riper tomatoes were more susceptible to mechanical damage (Olorunda and Tung, 1985). Tomatoes handled at "turning" stage $(10 \%$ $30 \%$ red coloration on the surface) developed four times more bruising injury than those handled at mature-green stage and eight times more than immature-green tomato (Halsey and Showalter, 1953). Internal bruising was more pronounced on tomatoes handled at breaker-stage than at mature-green stage (Sargent et al., 1989). Mature peaches also had larger bruise volumes and were more susceptible to bruising than less-mature peaches (Hung and Prussia, 1989). Conversely, green peaches were more susceptible to bruising than ripe ones (Vergano et al.,
1991), and susceptibility of apples to bruising decreased as the fruit ripened (Diener et al., 1979).

The demand for Roma-type tomatoes has increased rapidly in recent years due to both its desirable sensory characteristics and high concentrations of bioactive constituents, such as vitamin $\mathrm{C}$, carotenoids, lycopene, and polyphenols (Muratore et al., 2005). However, most research on mechanical injury has been conducted on standard round-type tomatoes, and there is currently little reliable postharvest information on high-flavor, specialty tomatoes. This study was designed to evaluate the effects of physical impacts and ripeness stage on selected quality parameters of Roma-type tomato.

\section{Materials and Methods}

Plant materials. Roma tomatoes ('BHN 467') were hand-harvested at mature-green color stage near Immokalee, FL, and transported the same day to the Postharvest Horticulture Laboratory at the University of Florida, Gainesville. Tomatoes were stored under simulated commercial conditions in sealed containers with the air flow containing $100 \mu \mathrm{L} \cdot \mathrm{L}^{-1}$ ethylene at $20{ }^{\circ} \mathrm{C}$ and $90 \% \mathrm{RH}$. Fruit were removed from ethylene upon reaching the desired stage (in 2-4 d), namely breaker $(<10 \%$ red coloration), pink $(30 \%$ $60 \%$ red coloration), or light-red ripeness stage $(60 \%-90 \%$ red color). At this point, fruits were sorted by size $(\approx 90 \mathrm{~g})$ and color (breaker, pink, or light-red), washed with 150-ppm chlorine solution, rinsed with tap water, and air-dried. Following impact treatment, two fruit were placed in a vented clamshell (Pactive, Model No. 9753; $110 \times$ $130 \times 70 \mathrm{~mm} ; 35$ clamshells per treatment) and ripened at $20{ }^{\circ} \mathrm{C}$.

Commercial impact simulation. Previous observations of commercial tomato packing lines showed that Roma tomatoes are dropped several times during handling from heights $>40 \mathrm{~cm}$. Subsequent tests in the laboratory determined that a single, $40-\mathrm{cm}$ drop reduced postharvest life as indicated by increased ethylene production and respiration rate (Lee et al., 2004). However, impact tests conducted by dropping individual Roma fruit were deemed to be unreliable because the fruit tended to rotate during the fall. Therefore, a pendulum impactor was selected due to its inherently great precision and repeatability in inducing impacts equivalent to a 40-cm vertical drop (Lee, 2005).

To better reflect commercial handling conditions in this study, each Roma tomato was impacted twice at the same location by a pendulum impactor. Because tomato fruit respond differently to mechanical stress depending on the impacted tissues, impacts were made over the locules that are most visibly affected and vulnerable tissue to bruising (Moretti et al., 1998). The pendulum impactor consisted of two steel support stands $(49 \mathrm{~cm})$ that were connected by a steel crossbar. A fabric pocket was suspended from the center of the cross-bar to secure and properly 
orient the tomato so that the impact would strike over the locule. The pendulum was a lead sinker $(230 \mathrm{~g} ; 3.5 \times 4.7 \times 3.5 \mathrm{~cm}$; oval shape) coated with a thin plastic material (Plasti-dip, Performix) to provide a smooth surface. It was attached at each end by nylon string that was attached to the cross-bar (33 $\mathrm{cm}$ apart). A vertical bar stand was located in the center of the platform, perpendicular to the support stand; the height was marked to indicate the pendulum angle equivalent to the desired vertical drops of $40 \mathrm{~cm}$.

The pendulum angle necessary to produce the equivalent angular impact force of a $40-\mathrm{cm}$ vertical drop was calculated using the following general formula:

$$
M r g=m h g
$$

where $M=$ mass of pendulum (230 g), $r=$ unknown vertical drop height of pendulum, $g=$ gravitational acceleration constant $\left(9.8 \mathrm{~m} \cdot \mathrm{s}^{-2}\right), m=$ mass of tomato $(\approx 90 \mathrm{~g})$, and $h=$ vertical drop height of tomato $(40 \mathrm{~cm})$. By solving for $r$, the equivalent pendulum angle was determined to be $58.3^{\circ}$. Each impact location (on the equator over the locule) was identified with white paint marker and was impacted twice. The pendulum was caught after each impact.

Respiration rate and ethylene production. The same 10 fruit were used for measuring respiration and ethylene production repeatedly during ripening. Two tomatoes were weighed, placed in a $1025-\mathrm{mL}$ plastic container $(\mathrm{n}=5)$ with loosely fitting lid and held at $20{ }^{\circ} \mathrm{C}$. Respiration and ethylene measurements were conducted by sealing each container for $1 \mathrm{~h}$, after which 0.5 and $1.0 \mathrm{~mL}$ of the headspace was removed through a septum by syringes to quantify carbon dioxide and ethylene, respectively. The initial measurement was conducted immediately after impact to observe the immediate response of tomato to the impact stress. Significant increases in ethylene production shortly after impact (5-60 min) had been reported by Miller (1992) and Lee (2005). Measurements were made daily for the first $3 \mathrm{~d}$, after that every other day. Carbon dioxide concentration was measured using a gas chromatograph (series 580; GOW MAC, Bridgewater, NJ) fitted with a thermal conductivity detector and Porapac Q column ( $4 \mathrm{ft} \times 1 / 8 \mathrm{in})$. The flow rate of the carrier gas (helium) was $25 \mathrm{~mL} \cdot \mathrm{min}^{-1}$, and the oven and injector/detector were set at $40^{\circ} \mathrm{C}$ and ambient $\left(\approx 25^{\circ} \mathrm{C}\right)$, respectively. Ethylene production was measured using a gas chromatograph (Tracor 540; Tremetrics, Austin, TX) fitted with a photoionization detector and alumina-packed column $(3 \mathrm{ft} \times 1 / 8 \mathrm{in})$. The flow rate of the carrier gas (helium) was $25 \mathrm{~mL} \cdot \mathrm{min}^{-1}$, and temperatures of oven and injector/detector were 50 and $100{ }^{\circ} \mathrm{C}$, respectively.

Firmness. Pericarp firmness was determined using an Instron Universal Testing Instrument (Model 4411; Canton, MA) equipped with a convex-tip probe (4-mm diameter) and 5-kg load cell. Each Roma tomato was cut equatorially with a sharp, double-bladed knife into 10-mm-thick slices; each slice was immediately placed on a solid plate. Zero height was established between the probe and the pericarp tissue at the junction of the external pericarp and radial pericarp of each slice. The probe was then driven with a crosshead speed of $10 \mathrm{~mm} \cdot \mathrm{min}^{-1}$, and the force was recorded at $2.5-\mathrm{mm}$ deformation. Fruits were either bilocular or trilocular, therefore two or three measurements, respectively, were made per fruit, and five individual fruits were evaluated per treatment every other day.

Electrolyte leakage. To examine the effect of impact on tissue disruption, electrolyte leakage was determined every other day on five individual fruits per treatment. Pericarp discs $(n=7) 7 \mathrm{~mm}$ in diameter were excised from the impacted side of one fruit using a No. 4 brass cork borer with a sharp edge, and locular gel tissue was discarded. The discs were rinsed with distilled water, blotted on Whatman \#4 filter paper, and transferred into $10 \mathrm{~mL}$ of $300 \mathrm{~mm}$ mannitol in a $50-\mathrm{mL}$ capped centrifuge tube. The tubes, each containing 7 pericarp discs, were placed in a oscillating shaker (Model 5850; Eberbach, Ann Arbor, MI) with gentle cycle (1 cycle/s) for $4 \mathrm{~h}$. EC was read using a conductivity bridge (YSI 3100 conductivity instrument; Yellow Springs, $\mathrm{OH}$ ), and then samples were frozen at $-20{ }^{\circ} \mathrm{C}$ for $24 \mathrm{~h}$. Samples were later thawed at room temperature, boiled in water for $15 \mathrm{~min}$, and the total conductivity reading was taken. All leakage data were expressed as a percentage of the total electrolyte conductivity [(initial conductivity reading/total conductivity reading) $\times 100]$.

Compositional analyses. Upon reaching the full-ripe stage (hue angle $\approx 35^{\circ}$, measured at the equator; day 3 , days $6-7$, and days 9-11 for light-red, pink and breaker, respectively), 10 whole fruit were individually homogenized with a blender (Model 908, Hamilton Beach/Proctor-Silex, Washington, $\mathrm{NC})$, followed by centrifugation at $8060 \mathrm{~g}$, at $5{ }^{\circ} \mathrm{C}$ for $20 \mathrm{~min}$. The resulting supernatant was filtered through cheesecloth and then frozen for later analysis. For soluble solids content (SSC), one to two drops of the supernatant were placed on the prism of a digital refractometer (Model 10480, ReichertJung, Mark Abbe Refractometer; Depew, $\mathrm{NY}$ ), and SSC was reported as ${ }^{\circ}$ Brix. The $\mathrm{pH}$ of the supernatant was determined using Corning model $140 \mathrm{pH}$ meter with a Corning G-P RJ probe (Corning Scientific Instruments, Medfield, MA). Total titratable acidity (TTA) was analyzed by an automatic titrimeter (no. 9-313-10, Fisher titrimeter; Fisher, Pittsburgh); each sample supernatant $(6 \mathrm{~g})$ diluted in $50 \mathrm{~mL}$ of distilled water was titrated with $0.1 \mathrm{~N} \mathrm{NaOH}$ to an endpoint of $\mathrm{pH}$ 8.2. TTA was expressed as percentage of citric acid.

endo-Polygalacturonase (PG, E.C. 3.2.1.15) activity. Five fruit of each treatment were evaluated every other day. After firmness measurements of each equatorial slice, the remaining pericarp tissue was excised, peeled, gel removed, and stored at $-20{ }^{\circ} \mathrm{C}$ for later analysis. Partially thawed tomato slices ( $3 \mathrm{~g})$ were homogenized with cold ethanol $(12 \mathrm{~mL})$ via polytron and centrifuged at $12,000 \mathrm{~g}$ for $20 \mathrm{~min}$ at $4{ }^{\circ} \mathrm{C}$. The pellet was washed with $25 \mathrm{~mL}$ of $80 \%$ cold ethanol followed by centrifugation at $12,000 \mathrm{~g}$ for $20 \mathrm{~min}$ at $4{ }^{\circ} \mathrm{C}$. The pellet was resuspended in $15 \mathrm{~mL}$ of extraction buffer consisting of $50 \mathrm{~mm}$ Trisma base and $1.2 \mathrm{M} \mathrm{NaCl}, \mathrm{pH} 7.0$, for $30 \mathrm{~min}$ in an ice bath and centrifuged at $12,000 \mathrm{~g}$ for $20 \mathrm{~min}$ at $4{ }^{\circ} \mathrm{C}$. The cell-free protein extract was used to measure polygalacturonase activity and total protein content. The bicinchoninic acid protein assay (Smith et al., 1985) was used to determine protein content with bovine serum albumin used as a standard.

For PG assays, $100 \mu \mathrm{L}$ of the cell-free protein extract was incubated with $500 \mu \mathrm{L}$ $\left(2 \mathrm{mg} \cdot \mathrm{mL}^{-1}\right)$ of polygalacturonic acid (from orange peel; Sigma Chemical Co., St. Louis) dissolved in buffer solution containing $30 \mathrm{~mm}$ $\mathrm{NaOAc}$ and $30 \mathrm{~mm} \mathrm{NaCl}(\mathrm{pH} 4.5)$ for $30 \mathrm{~min}$ at $34{ }^{\circ} \mathrm{C}$. Reducing groups generated by PG were assayed using the method of Milner and Avigad (1967), and PG activity was expressed as moles of D-galacturonic acid equivalents produced per milligram protein per minute.

Statistical analysis. The experiment was conducted using a completely randomized design. Statistical analysis was performed using the PC-SAS software package. All data were subjected to analysis of variance and treatment means were compared using Duncan's multiple range test $(P<0.05)$.

\section{Results and Discussion}

Respiration rate and ethylene production. The highest respiration rate of breaker-stage fruit was observed at day 0: 33 and 47 $\mathrm{mg} \cdot \mathrm{kg}^{-1} \cdot \mathrm{h}^{-1}$ for non-impacted fruit and impacted fruit, respectively (Fig. 1). Moretti et al. (1998) similarly reported that nonimpacted standard round-type tomato at breaker stage had $38 \mathrm{mg} \cdot \mathrm{kg}^{-1} \cdot \mathrm{h}^{-1}$ maximum respiration rate during ripening and that the respiration rate of fruit dropped from $40 \mathrm{~cm}$ on opposite sides at the equator was $20 \%$ higher. Regardless of ripeness stage, impacted fruit had higher respiration rates than control fruit $1 \mathrm{~h}$ after impact (day 0 ). At that time, Roma tomato impacted at breaker, pink, or light red stages had $41 \%$, $30 \%$, or $58 \%$ increased respiration rate, respectively, over non-impacted fruit. The increase in respiration following impact has been reported as a representative marker of commodities subjected to stress (Burton and Schulte-Pason, 1987; De Martino et al., 2006). Sturm and Chrispeels (1990) explained that this enhanced respiration rate from impact stress was due to demands for high amounts of hexoses used for synthesizing energy and providing carbon skeletons to make response compounds. In this study the respiration rates of impacted fruit at lightred stage or pink stage declined to the same level as non-impacted fruit after 2 and $3 \mathrm{~d}$, respectively, whereas that for fruit impacted 
at breaker stage remained higher than for non-impacted fruit throughout ripening.

Ethylene production of non-impacted, breaker Roma tomato peaked at $3.5 \mu \mathrm{L} \cdot \mathrm{kg}^{-1} \cdot \mathrm{h}^{-1}$ during ripening (Fig. 2). Double impacts

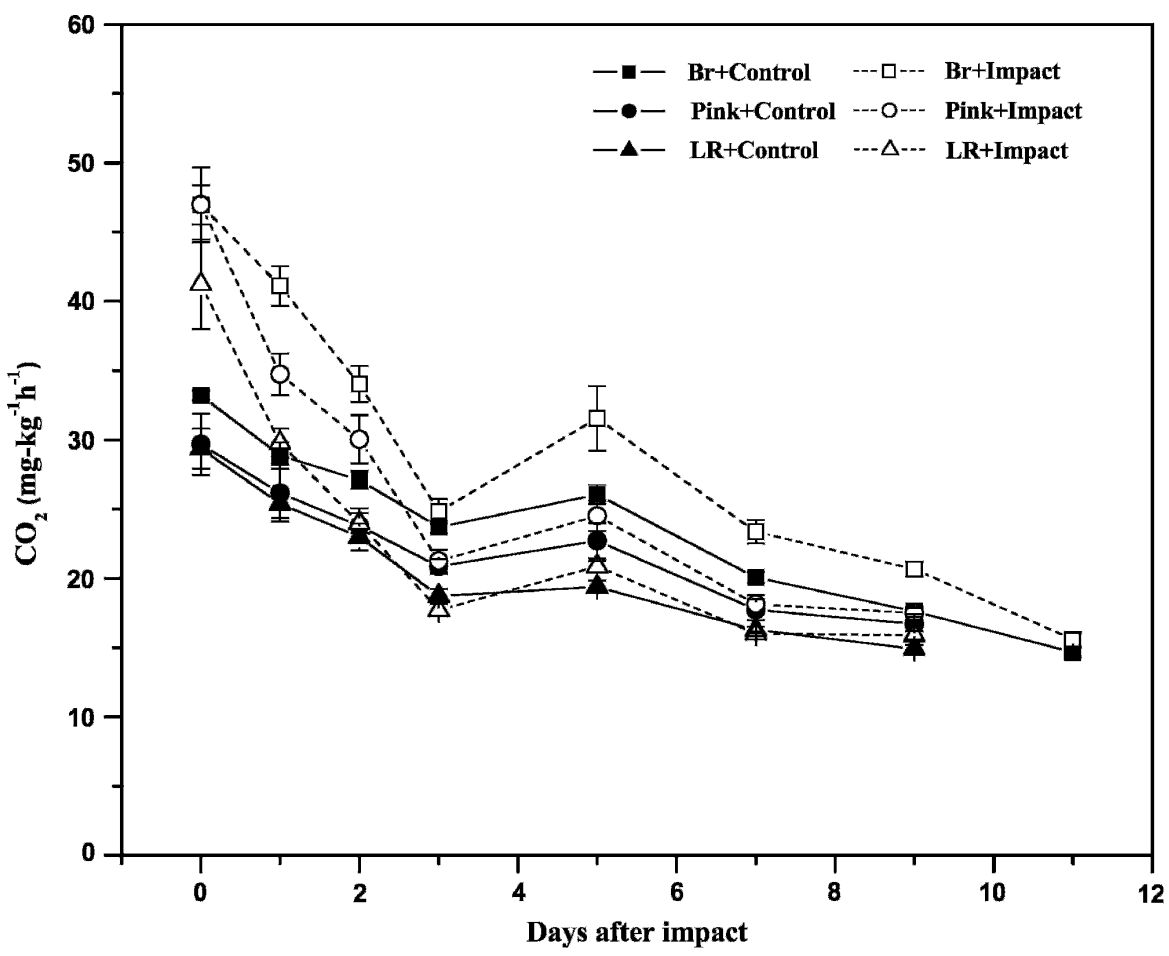

Fig. 1. Respiration rate of Roma-type tomato during ripening to full-ripe stage at $20{ }^{\circ} \mathrm{C}$. Individual fruit at each ripeness stage $(n=5)$ - breaker $(\boldsymbol{\bullet})$, pink $(\bullet)$, or light-red $(\boldsymbol{\Lambda})$ - was subjected to double impacts equivalent to two $40-\mathrm{cm}$ drops (open symbol for each ripeness stage). Vertical bar represents standard error.

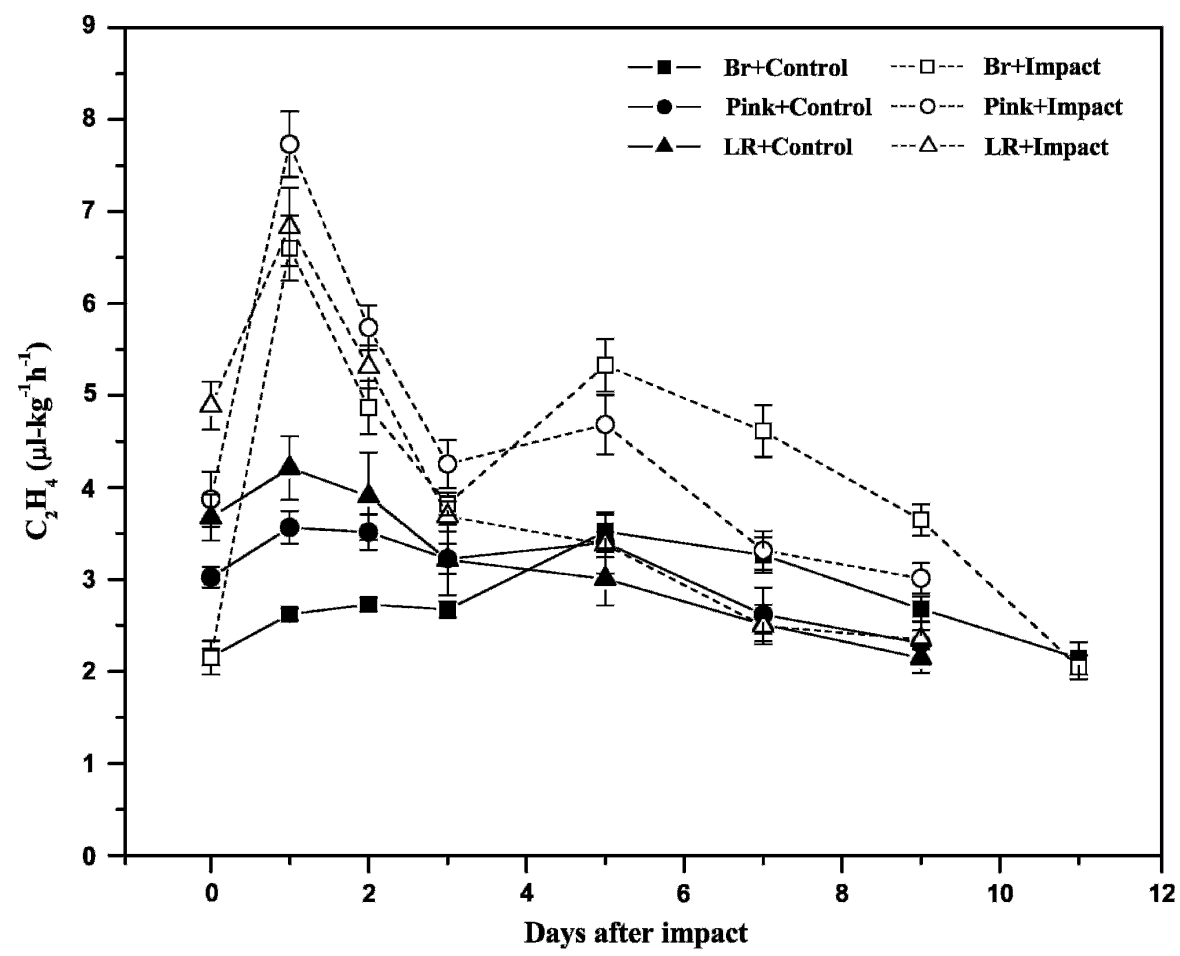

Fig. 2. Ethylene production of Roma-type tomato during ripening to full-ripe stage at $20{ }^{\circ} \mathrm{C}$. Individual fruit at each ripeness stage $(\mathrm{n}=5)$ - breaker $(\boldsymbol{\bullet})$, pink $(\bullet)$, or light-red $(\boldsymbol{\Delta})$ - was subjected to double impacts equivalent to two $40-\mathrm{cm}$ drops (open symbol for each ripeness stage). Vertical bar represents standard error. fruit receiving double impacts had peak ethylene at $7.7 \mu \mathrm{L} \cdot \mathrm{kg}^{-1} \cdot \mathrm{h}^{-1}$. Ethylene production tripled in fruits impacted at breaker stage, and those impacted at light-red stage had $60 \%$ increased ethylene production. Moretti et al. (1998) reported that maximum ethylene production for non-impacted round tomato at breaker stage was $\approx 4 \mu \mathrm{L} \cdot \mathrm{kg}^{-1} \cdot \mathrm{h}^{-1}$, while fruit at the same ripeness stage dropped twice from $40 \mathrm{~cm}$ (once on opposite sides of the fruit equator) induced a $125 \%$ increase. Similarly, De Martino et al. (2002) reported the highest ethylene production from impacted apricot fruit occurred after $24 \mathrm{~h}$; Miller (1992) also mentioned that many fruits and vegetables exhibit significant increases in ethylene production shortly after impact (5-60 $\mathrm{min})$. Increases in 1-aminocyclopropane-1-carboxylic acid (ACC) and its conversion to ethylene were mentioned as the mechanism by which stressed fruits produce elevated amounts of ethylene (Yang and Hoffman, 1984), which was confirmed by increased accumulation of ACS, ACO, and E4 mRNAs in wounded tomato (Tatsuki and Mori, 1999; Yokotani et al., 2004). In the present study the climacteric peak in ethylene production was observed only for breakerstage fruits at day 5, when ethylene production rate of fruit subjected to double impacts was $\approx 60 \%$ higher than non-impacted fruit. Based on these data, fruit at earlier stages of ripening exhibited the greatest respiratory and ethylene production increases in response to impact.

Firmness. Roma-type tomato softened during ripening at $20{ }^{\circ} \mathrm{C}$. Initial pericarp firmness at breaker, pink, and light-red ripeness stages averaged 14.0, 9.5, and $6.8 \mathrm{~N}$, respectively (Fig. 3). Impact-free fruit at breaker stage maintained initial firmness during the first $2 \mathrm{~d}$, after which firmness decreased nearly $50 \%$ by $4 \mathrm{~d}$. On the contrary, the firmness of fruits impacted at breaker stage decreased continuously during storage. Impacted breaker-stage fruit reached full-ripe stage ( $4 \mathrm{~N}$ ) by $1-2 \mathrm{~d}$ faster than nonimpacted fruit. This softening was probably due to accelerated ripening incited by the impact stress, as noted in apricot (De Martino et al., 2006). In contrast, there was no significant difference in pericarp firmness between non-impacted and impacted Roma tomatoes at pink or light-red ripeness stage. The result that fruit impacted at breaker stage were more sensitive to impact stress than those impacted at pink or light-red stages might be explained in terms of turgidity. Garcia et al. (1995) reported that turgid apple fruits were more susceptible to mechanical injury than less turgid fruit because stresses in the turgid tissues were higher. This result was also supported by findings that green peaches were more susceptible to bruising than ripe ones (Vergano et al., 1991).

Electrolyte leakage. Electrolyte leakage (EL) was tracked during ripening as an indicator of cellular membrane integrity of bruised fruit (Wilson and McMurdo, 1981). Although EL declined steeply during the first $2 \mathrm{~d}$ of storage, it increased during subsequent 
ripening (Fig. 4). This observation is consistent with the deterioration of cell membranes in pericarp tissue during tomato ripening. Increased membrane permeability during tomato ripening was reported by Malacrida et al. (2006). The higher initial values for EL reflect many stresses induced during setup procedures such as sorting, washing, and

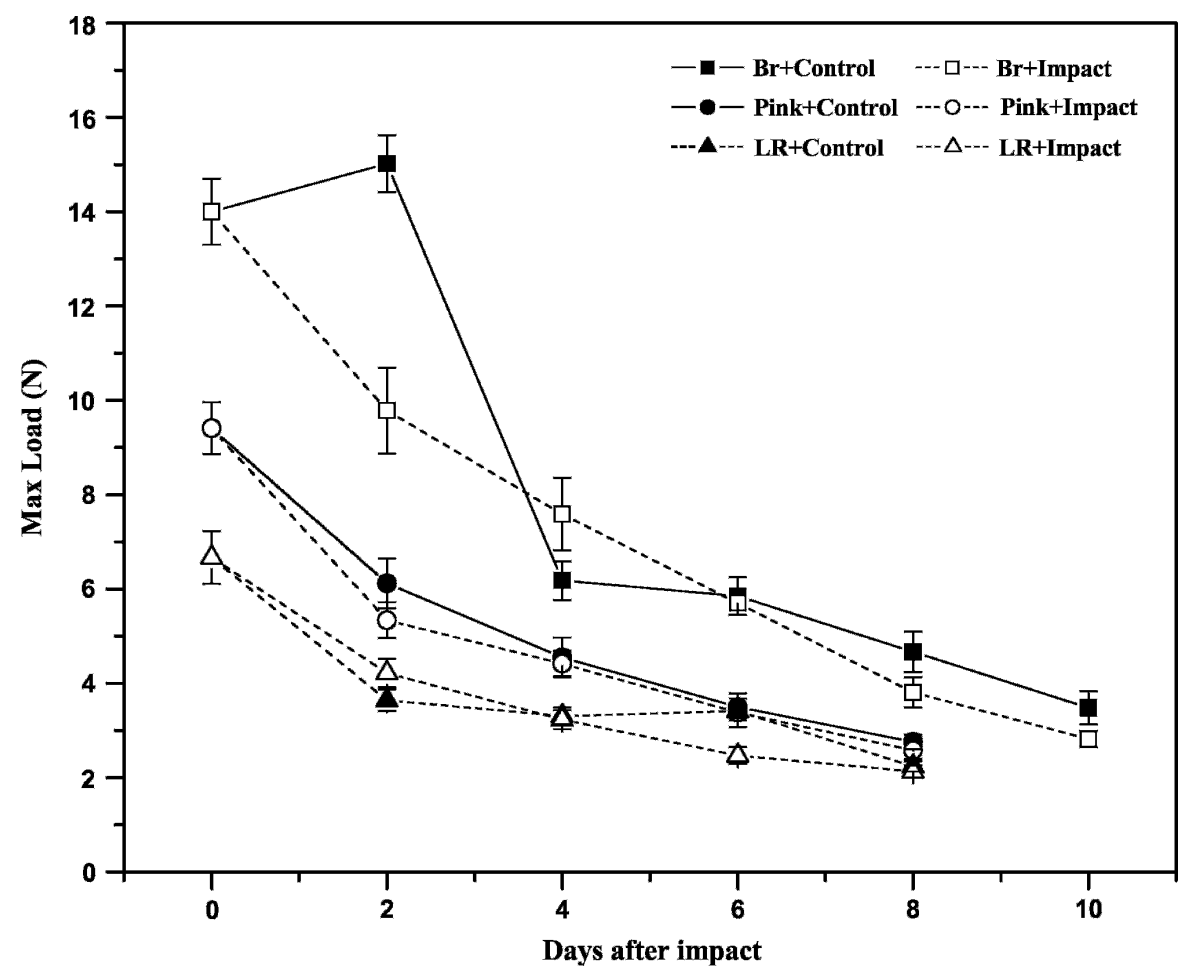

Fig. 3. Pericarp firmness of Roma-type tomato during ripening to full-ripe stage at $20^{\circ} \mathrm{C}$. Individual fruit at each ripeness stage $(n=5)$ - breaker $(\boldsymbol{\square})$, pink $(\bullet)$, or light-red $(\boldsymbol{\Delta})$-was subjected to double impacts equivalent to two $40 \mathrm{~cm}$ drop (open symbol for each ripeness stage). Vertical bar represents standard error.

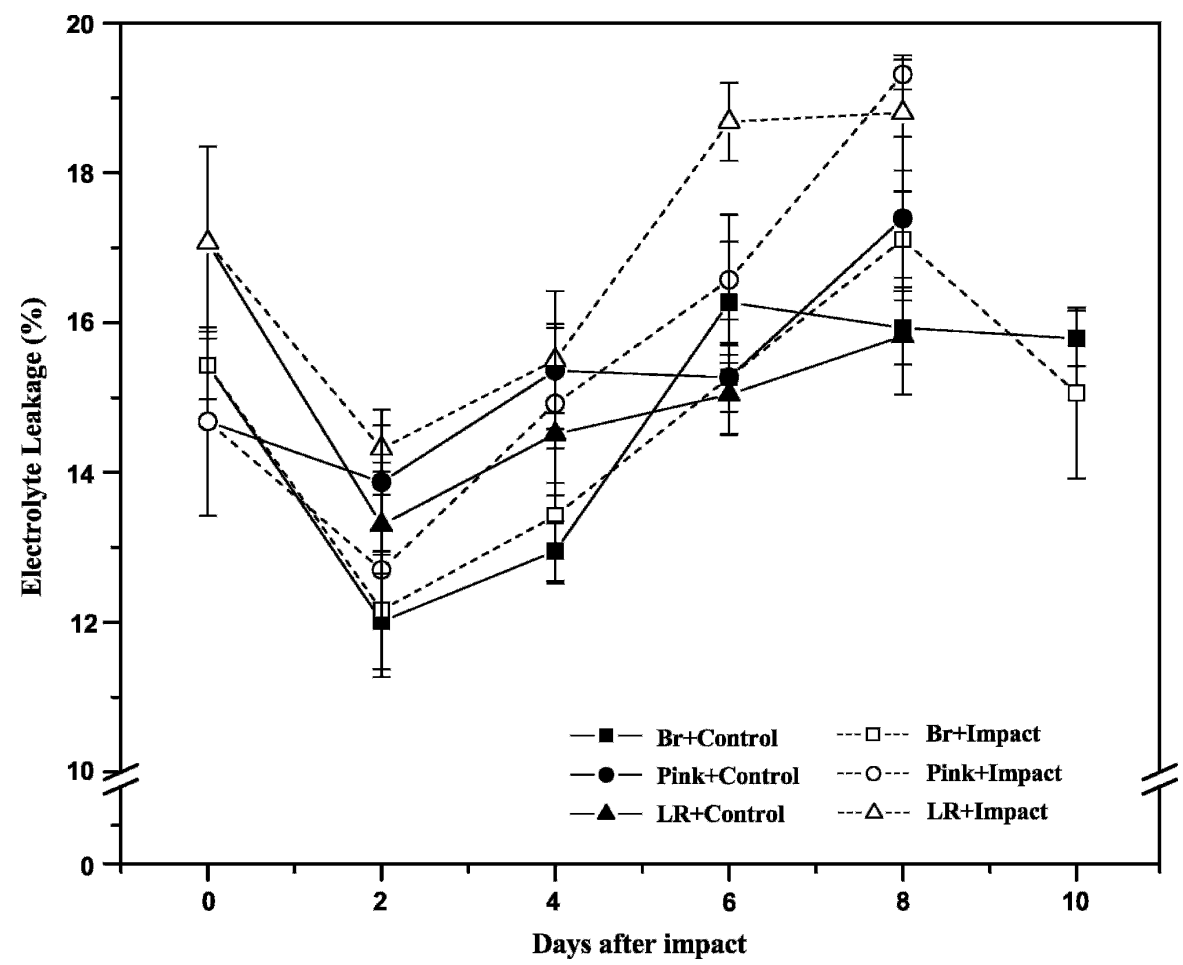

Fig. 4. Electrolyte leakage of Roma-type tomato during ripening to full-ripe stage at $20^{\circ} \mathrm{C}$. Individual fruit at each ripeness stage $(n=5)$ - breaker $(\boldsymbol{\square})$, pink $(\bullet)$, or light-red $(\boldsymbol{\Delta})$-was subjected to double impacts equivalent to two 40-cm drops (open symbol for each ripeness stage). Vertical bar represents standard error.

impact treatment; tomato fruit seems to have ability to recover from these stresses. Sargent et al. (1989) reported that small impact bruises on mature-green, round-type tomato were no longer apparent after several days of ripening at $20{ }^{\circ} \mathrm{C}$. Wounding is known to activate physiological and biochemical mechanisms through the induction or changes of enzyme activities and the transcriptional activation of specific genes within a few minutes, several hours, or a few days (Leon et al., 2001; Tatsuki and Mori, 1999).

Impact stress led to increased EL, which was higher at light-red stage than at breaker or pink stages. EL of fruit impacted at lightred stage was $27 \%$ higher than that of nonimpacted fruit at day 6 . In addition, the fruit impacted at light-red stage showed higher EL than control fruit during the entire ripening period, while fruit impacted at pink or breaker stages, did not show increased EL until day 4 or 6 , respectively. At that time, pink and breaker fruit had reached the light-red stage. This observation supports the hypothesis that the effect of impact on cell membrane appears when tomato reaches a certain advanced ripeness stage, in this case late light-red stage.

Compositional analyses. Soluble solids content (SSC), total titratable acidity (TTA), and $\mathrm{pH}$ were measured at full-ripe stage (hue angle $\approx 35^{\circ}$ ). Impact had no effect on SSC within each ripeness stage or on TTA $(0.37 \%-0.42 \%)$ irrespective of ripeness stage (Table 1). SSC was lower for light-red impacted fruit than impacted and non-impacted fruit at either breaker or pink stages. What triggered this response is not clear. Studies conducted by Moretti et al. (1998) noted no significant difference in SSC between bruised and unbruised tissue of standard round-type tomatoes; TTA decreased in locule tissue but not in pericarp or placental tissues. In contrast, sensory panelists detected altered tomato flavor in ripe round tomatoes that had been dropped from $40 \mathrm{~cm}$ at the breaker stage (Moretti and Sargent, 2000). Moretti et al. (2002) speculated that alterations in aroma volatile profiles following physical impact might be incited by disruption in the metabolism of fatty acids (linoleic and linolenic acids), amino acids (isoleucine), and pigments (cyclic and open-chain carotenoids) during fruit ripening. Elucidation of the effect of physical impact on the flavor of Roma tomato would require extensive sensory panel analysis and volatile analysis.

endo-Polygalacturonase (PG, E.C. 3.2.1.15) activity. The initial polygalacturonase (PG) activity of nonimpacted fruit at breaker, pink, and light-red ripeness stages was 30,430, and $600 \mu \mathrm{mol} \cdot \mathrm{mg}^{-1} \cdot \mathrm{min}^{-1}$ (D-galacturonic acid), respectively (Fig. 5). Impacts increased PG activity in pink and light-red stage fruit by $\approx 20 \%$ over nonimpacted fruit at day 2 and again at day 8. Impact had no significant effect on PG activity in breaker fruit until day 8 ; breaker fruit only reached the initial $\mathrm{PG}$ activity (around $600 \mu \mathrm{mol} \cdot \mathrm{mg}^{-1} \cdot \mathrm{min}^{-1}$ ) and external color of light-red fruit at day 6 . Thus the effect of impact stress on PG activity was negligible until Roma tomato attained 
Table 1. Compositional analyses of Roma-type tomato impacted at several ripeness stages at full-ripe stage (hue angle $\approx 35^{\circ}$; day 3 , day 6-7, and day 9-11 for light-red, pink, and breaker, respectively).

\begin{tabular}{lcccc}
\hline Treatment & SSC $^{\mathrm{z}}\left({ }^{\circ}\right.$ Brix $)$ & TTA $(\%)$ & Sugar/acid ratio & $\mathrm{pH}$ \\
\hline Br: No impact & $4.04 \mathrm{ab}$ & $0.42 \mathrm{a}^{\mathrm{y}}$ & $9.83 \mathrm{ab}$ & $4.49 \mathrm{~b}$ \\
Br: Impacted & $4.62 \mathrm{a}$ & $0.42 \mathrm{a}$ & $11.2 \mathrm{a}$ & $4.52 \mathrm{ab}$ \\
Pink: No impact & $3.95 \mathrm{~b}$ & $0.41 \mathrm{a}$ & $9.88 \mathrm{ab}$ & $4.52 \mathrm{ab}$ \\
Pink: Impacted & $4.19 \mathrm{ab}$ & $0.38 \mathrm{a}$ & $10.9 \mathrm{a}$ & $4.55 \mathrm{a}$ \\
LR: No impact & $3.53 \mathrm{bc}$ & $0.38 \mathrm{a}$ & $9.33 \mathrm{~b}$ & $4.55 \mathrm{a}$ \\
LR: Impacted & $3.18 \mathrm{c}$ & $0.37 \mathrm{a}$ & $8.65 \mathrm{~b}$ & $4.52 \mathrm{ab}$ \\
\hline
\end{tabular}

${ }^{2} \mathrm{SSC}$, soluble solids content; TTA, total titratable acidity (citric acid equivalent); Br, Pink, or LR = breaker, pink, or light-red ripeness stages, respectively $(n=10)$. Columns with different letters are significantly different at $P<0.05$, according to Duncan's multiple range test.

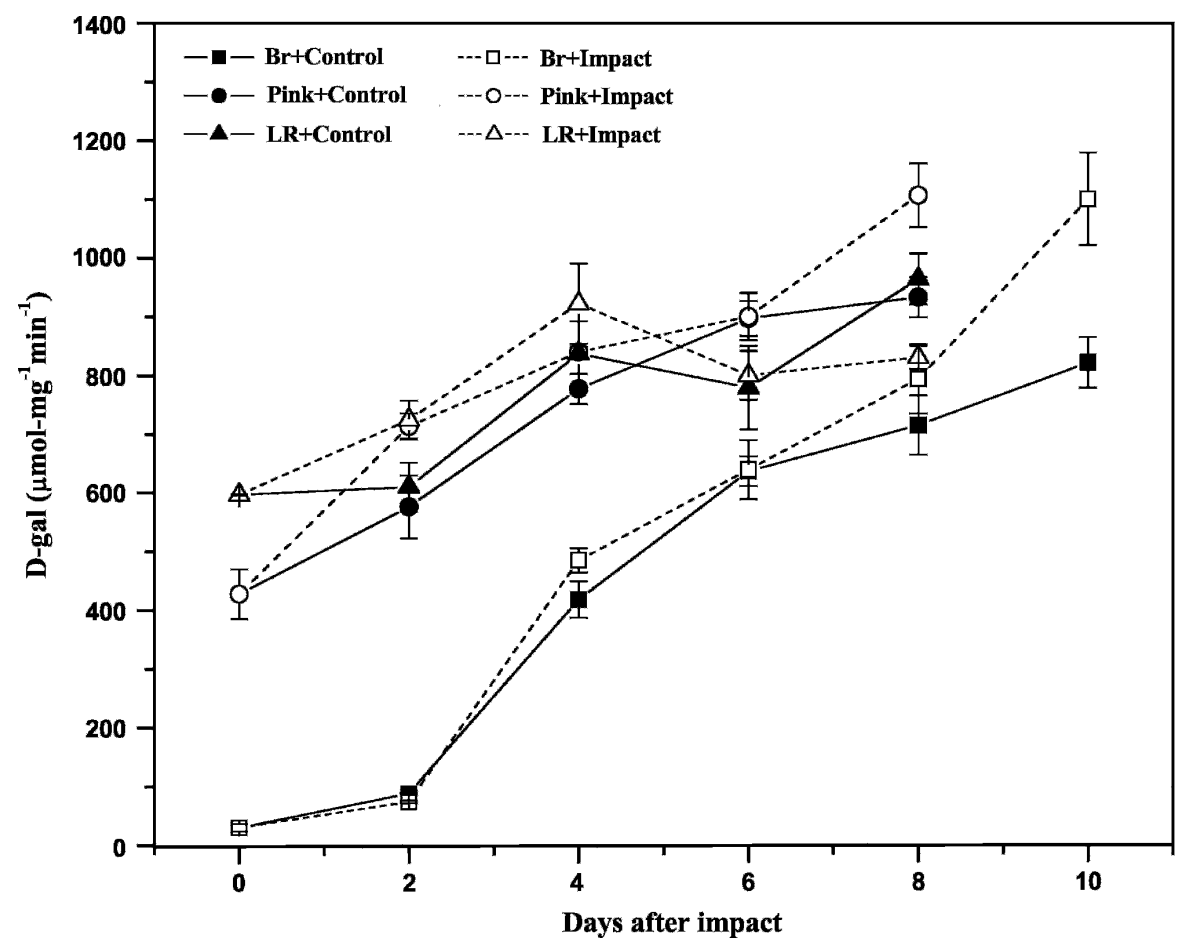

Fig. 5. Polygalacturonase (PG) activity in pericarp tissue of Roma-type tomato during ripening to full-ripe stage at $20^{\circ} \mathrm{C}$. Individual fruit at each ripeness stage — breaker $(\boldsymbol{\square})$, pink $(\bullet)$, or light-red $(\boldsymbol{\Delta})$-was subjected to double impacts equivalent to two 40 -cm drops (open symbol for each ripeness stage). Each point indicates the mean of 5 fruits, 3 measurements per fruit. Vertical bar represents standard error. PG activity is expressed as micromolecular D-galacturonic acid equivalents produced per milligram of protein per minute.

light-red ripeness stage, similar to results of electrolyte leakage. Increases in PG activity observed in impacted fruit indicate that double impacts equivalent to $40 \mathrm{~cm}$ drop accelerated cellular membrane breakdown or softening. On the other hand, because only extractable PG was analyzed in the present study, it is possible that PG tightly bound to the cell wall might be more easily extracted from the impacted-bruised tissue.

Fruit impacted at breaker, pink and lightred ripeness stages had $\mathrm{PG}$ activity increases of $34 \%, 19 \%$, and $10 \%$, respectively, at around full-ripe stage (day 4, 8, and 10 respectively for light-red, pink, and breaker stage; Fig. 5). This observation also supports the observation that breaker fruit is more sensitive to impact stress than fruit at pink or light-red stages. Because PG in tomato fruit is inducible by ethylene (Sitrit and Bennett, 1998), the higher ethylene production induced by impact stress in fruit at lessadvanced stages of ripening (Fig. 2) most and PG activity after day 6 , coincident with reaching light-red ripeness stage. Double impacts of $40 \mathrm{~cm}$ at breaker, pink, or lightred stage did not significantly affect SSC and TTA. To clarify the effect of impact on the flavor quality of Roma tomato, further analysis of aroma volatiles and use of a sensory panel is suggested.

\section{Literature Cited}

Brusewitz, G.H. and J.A. Bartsch. 1989. Impact parameters related to post harvest bruising of apples. Trans. ASAE 32:953-957.

Burton, C.L. and N.L. Schulte-Pason. 1987. Carbon dioxide as an indicator of fruit impact damage. HortScience 22:281-282.

Clark, L.J., R. Walser, and E.W. Carpenter. 1999 Tomato variety trial, 1998. Safford Agricultural Center. November 2004. <http://ag.arizona.edu/ pubs/crops/az1143/>.

De Martino, G., R. Massantini, R. Botondi, and F. Mencarelli. 2002. Temperature affects impact injury on apricot fruit. Postharvest Biol. Technol. 25:145-149.

De Martino, G., K. Vizovitis, R. Botondi, A Bellincontro, and F. Mencarelli. 2006. 1-MCP controls ripening induced by impact injury on apricots by affecting SOD and POX activities. Postharvest Biol. Technol. 39:38-47.

Diener, R.G., K.C. Elliot, P.E. Nesselroad, M. Ingle, R.E. Adams, and S.H. Blizzard. 1979 Bruise energy of peaches and apples. Trans. ASAE 22:287-290.

Garcia, J.L., M. Ruiz, and P. Barreiro. 1995. Factors influencing mechanical properties and bruise susceptibility of apples and pears. J. Agr. Eng. Res. 61:11-18.

Halsey, L.H. and R.K. Showalter. 1953. How does tomato maturity affect market quality, p. 134135. Proc. Assoc. of Southern Agr. Workers.

Hung, Y.C. and S.E. Prussia. 1989. Effect of maturity and storage time on the bruise susceptibility of peaches. Trans. ASAE 32:13771382

Lee, E. 2005. Quality changes induced by mechanical stress on Roma-type tomato and potential alleviation by 1-methylcyclopropene. Univ. of Florida, Gainesville, FL. MS Thesis.

Lee, E., A.D. Berry, and S.A. Sargent. 2004 Impact thresholds to maximize postharvest quality of Roma-type tomato. Proc. Fla. State Hort. Soc. 117:373-. 377.

Leon, J., E. Rojo, and J.J. Sanchez-Serrano. 2001 Wound signaling in plants. J. Expt. Bot. 52: $1-9$.

MacLeod, R.F., A.A. Kader, and L.L. Morris 1976. Stimulation of ethylene and $\mathrm{CO}_{2}$ production of mature-green tomatoes by impact bruising. HortScience 11:604-606.

Malacrida, C., E.M. Valle, and S.B. Boggio. 2006. Postharvest chilling induces oxidative stress response in the dwarf tomato cultivar MicroTom. Physiol. Plant. 127:10-18.

Marshall, D.E. and R.C. Brook. 1999. Reducing bell pepper bruising during postharvest handling. HortTechnology 9:254-258.

Miller, A.R. 1992. Physiology, biochemistry and detection of bruising (mechanical stress) in fruits and vegetables. Postharvest News Inform. $3(3): 53 \mathrm{~N}-58 \mathrm{~N}$.

Miller, A.R., J.P. Dalmasso, and D.W. Kretchman. 1987. Mechanical stress, storage time, and temperature influence cell wall-degrading enzyme, firmness and ethylene production by cucumber. J. Amer. Soc. Hort. Sci. 112:666671. 
Milner, Y. and G. Avigad. 1967. A copper reagent for the determination of hexuronic acids and certain ketohexoses. Carbohydr. Res. 4:359-361.

Moretti, C.L., E.A. Baldwin, S.A. Sargent, and D.J. Huber. 2002. Internal bruising alters aroma volatile profiles in tomato fruit tissue. HortScience 37:378-382.

Moretti, C.L., S.A. Sargent, D.J. Huber, A.G. Calbo, and R. Puschmann. 1998. Chemical composition and physical properties of pericarp, locule, and placental tissues of tomatoes with internal bruising. J. Amer. Soc. Hort. Sci. 123:656-660.

Moretti, C.L. and S.A. Sargent. 2000. Flavor alteration in tomato fruits due to internal bruising. Sci. Agr. 57:385 (abstr.).

Morris, J.R., D.L. Cawthon, and J.W. Fleming. 1979. Effects of temperature and $\mathrm{SO}_{2}$ addition on quality and postharvest behavior of mechanically-harvested juice grapes in Arkansas. J. Amer. Soc. Hort. Sci. 104:166-169.

Muratore, G., F. Licciardello, and E. Maccarone. 2005. Evaluation of the chemical quality of a new type of small-sized tomato cultivar, the plum tomato (Lycopersicon lycopersicum). Ital. J. Food Sci. 17:75-81.
O’Brien, M., S.J. Leonard, G. Marsh, and N.A. Olson. 1972. Processing losses of tomatoes as affected by harvesting and handling procedures. Trans. ASAE 15:563-568.

Olorunda, A.O. and M.A. Tung. 1985. Simulated transit studies on tomatoes; effects of compressive load, container, vibration and maturity on mechanical damage. J. Food Technol. 20: 669-678.

Sargent, S.A., J.K. Brecht, and J.J. Zoellner. 1989 Assessment of mechanical damage in tomato packing lines. ASAE Paper No. 89-6060. ASAE, St. Joseph, MI.

Sargent, S.A., J.K. Brecht, and J.J. Zoellner. 1992. Sensitivity of tomatoes at mature-green and breaker ripeness stages to internal bruising. J. Amer. Soc. Hort. Sci. 117:119-123.

Sitrit, Y. and A.B. Bennett. 1998. Regulation of tomato fruit polygalacturonase mRNA accumulation by ethylene: a re-examination. Plant Physiol. 116:1145-1150.

Smith, P.K., R.I. Krohn, G.T. Hermanson, A.K. Mallia, F.H. Gartner, M.D. Provenzano, E.K Fujimoto, N.M. Goeke, B.J. Olson, and D.C. Klenk. 1985. Measurement of protein using bicinchoninic acid. Anal. Biochem. 150:76-85.
Sturm, S. and M.J. Chrispeels. 1990. cDNA cloning of carrot extracellular $\beta$-fructosidase and its expression in response to wounding and bacterial infection. Plant Cell 2:1107-1119.

Tatsuki, M. and H. Mori. 1999. Rapid and transient expression of 1-aminocyclopropane-1-carboxylate synthase isogenes by touch and wound stimuli in tomato. Plant Cell Physiol. 40:709-715.

Vergano, P.J., R.F. Testin, and W.C. Newall. 1991. Peach bruising: Susceptibility to impact, vibration, and compression. Trans. ASAE 34: 2110-2116.

Wilson, J.M. and A.C. McMurdo. 1981. Chilling injury in plants, p. 145-172. In: G.J. Morris and A. Clarke (eds.). Effects of low temperatures on biological membranes. Academic Press, New York.

Yang, S.F. and N.E. Hoffman. 1984. Ethylene biosynthesis and its regulation in higher plants. Ann. Rev. Plant Physiol. 35:155-189.

Yokotani, N., S. Tamura, R. Nakano, A. Inaba, W.B. McGlasson, and Y. Kubo. 2004. Comparison of ethylene- and wound-induced responses in front of wild-type, rin and nor tomatoes. Postharvest Biol. Technol. 32:247252. 